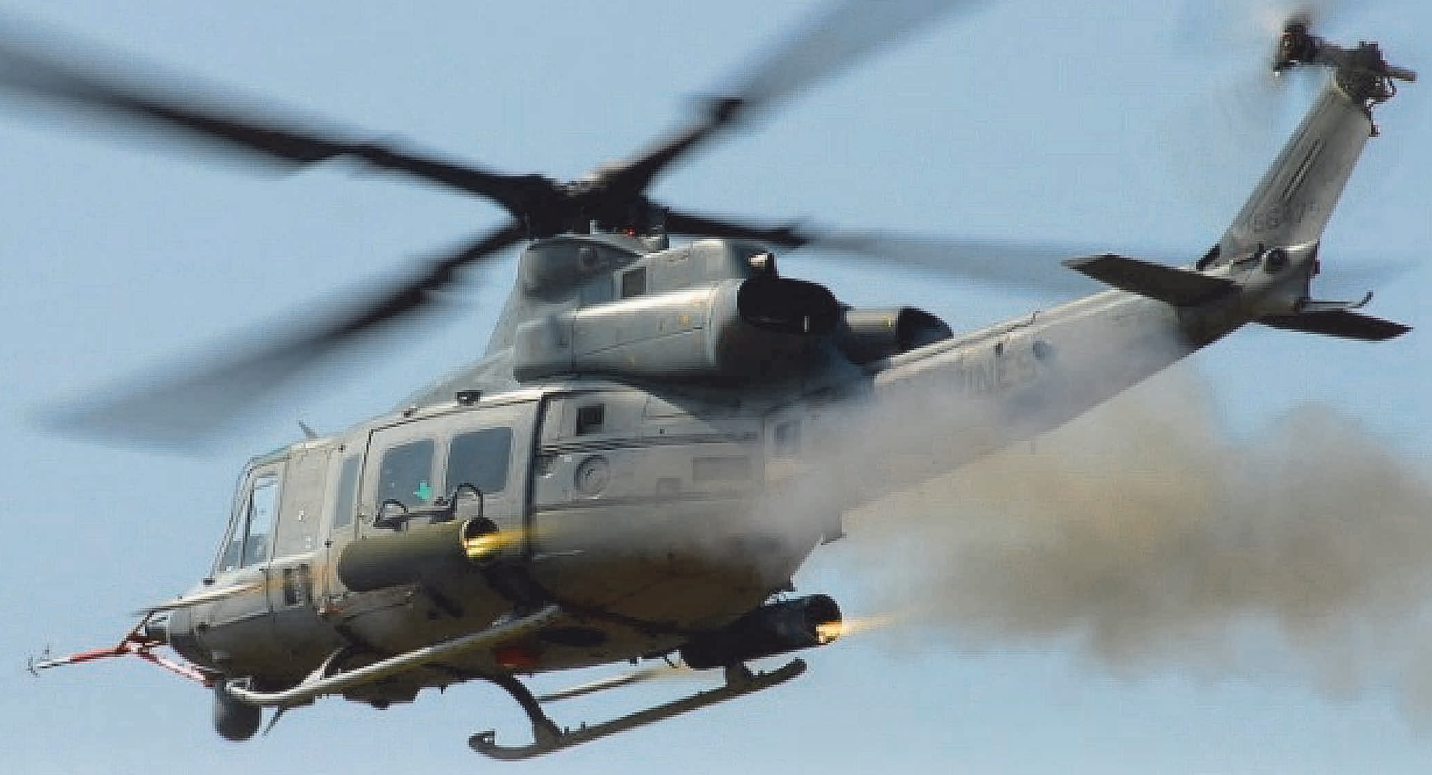

Sipos Károly* - Rajnai Iván**

\title{
A Bell UH-1-es helikopter története és hazai vonatkozásai
}

\section{A BeLL UH-1-ES HELIKOPTER MEGJELENÉSE}

Az amerikai Bell UH-1-es szállítóhelikopter prototípusa 1956-ban repült először. A többcélú katonai szállítóhelikopter fejlesztője és gyártója a Bell Helicopter Textron. A Bell Helicopters hadrendbe állításakor a $\mathrm{HU}-1 \mathrm{~A}$ (Helicopter Utility - kiszolgáló helikopter) típusjelölést adta az új helikopternek. (Ebből a betűszóból ered a Huey becenév.) Később módosították a jelölési rendszert, így kapta meg a típus (Bell 204-es modell) az UH-1-es nevet. A Bell több polgári jelzésű változatot is készített. Ilyen a Bell 204es, a hosszabbított törzsủ 205-ös és 210 -es, továbbá a két hajtóműves 212-es, és a két hajtóműves, négy forgószárnylapátos 412-es, amelyet ma is gyárt a Bell az EPI változatban.

ÖSSZEFOGLALÁS: Az UH-1-es helikopter különböző polgári és katonai változataiból $16000 \mathrm{db}$ készült, ezzel a legelterjedtebb helikopter a világon. A típus hosszú időtartamú gyártása és üzemben tartása napjainkig csak úgy volt lehetséges, hogy a gyártó folyamatos típus-korszerüsítést hajtott végre és egyre újabb, növelt képességű típusváltozatot bocsátott ki. A cikk a szállitóhelikopter hazai rendszeresitésére tett kísérletet is ismerteti.

KULCSSZAVAK: UH-1 helikopter, fejlesztés, típustörténet, hazai rendszeresítés

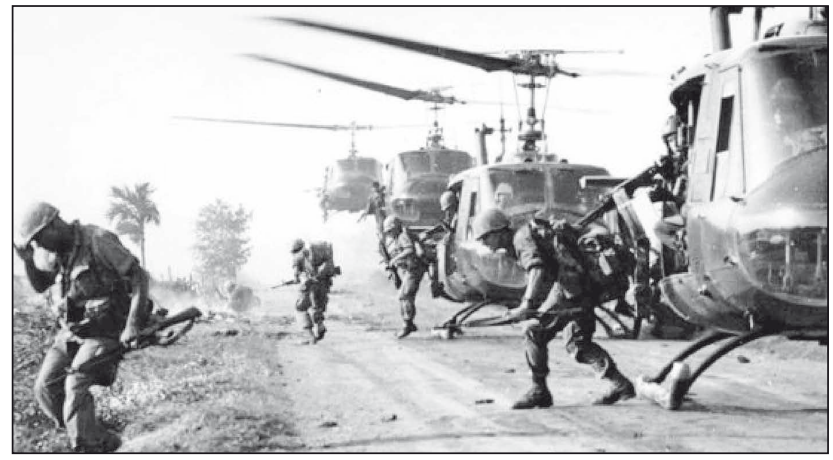

2. ábra. UH-1-es helikopter-kötelék lövészeket rak ki Vietnamban

ABSTRACT: More than 16,000 pieces of several commercial and military versions of the UH-1 helicopter have been built, so it is the most common helicopter in the world. The long-run production and operation of this helicopter type up to now was possible only in the way, in which the manufacturer continuously modernized it and marketed newer and newer variants with enhanced capabilities. This article also deals with the attempt to enter this helicopter type into service in Hungary.

KEY WORDS: UH-1 helicopter, development, type history, domestic enter into service

* Helikoptervezető / közlekedésmérnök BsC, okleveles katonai vezető MsC

** HM Állami Légügyi Főosztály, repülőmérnök. ORCID: 0000-0002-0036-7932 
1963-tól, a vietnami háború során kezdték nagy számban alkalmazni a típust. Az UH-1-esből 1950-es évektől napjainkig több mint 16000 db-ot gyártottak. Napjainkban több mint 40 országban teljesít szolgálatot.

Az UH-1 Huey helikopter ezáltal napjaink legszélesebb körben alkalmazott katonai helikoptere. Létezik több olyan példánya is az $\mathrm{UH}-1$-esnek, amely már 30000 repült órát teljesített.

\section{A HELIKOPTER SZERKEZETI LEírÁsA}

A sárkányszerkezet teljesen könnyűfém építésű, emiatt a sérülések javítása könnyebb és egyszerübb, még tábori körülmények között is.

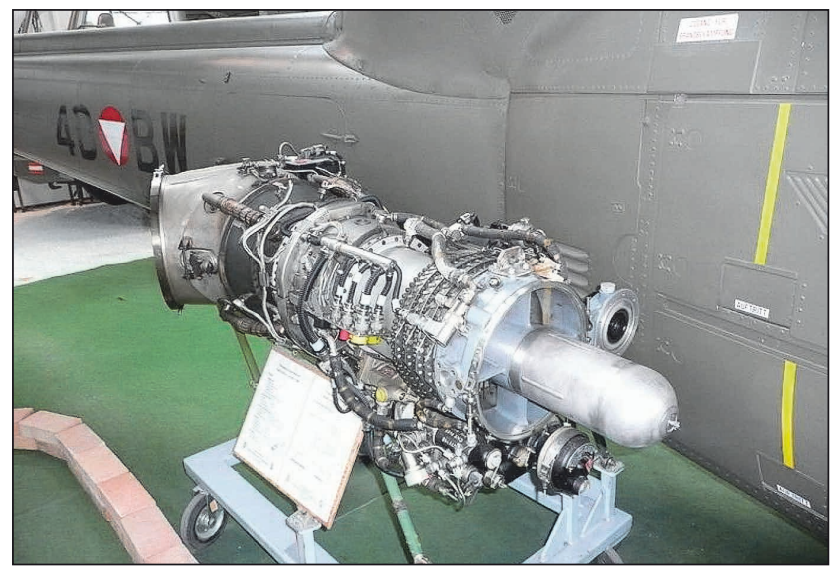

3. ábra. Az UH-1-es helikopter licence alapján épített Agusta-Bell AB-204-es helikopter Bristol-Siddley H 1200-as gázturbinás hajtómúve

A korai variánsokat (prototípusokat) egy 700 LE teljesítményű Lycoming XT-53-as gázturbinás hajtómüvel szerelték. Az alaptípus sajátossága volt a kétágú főrotor, amely egyszerű szerkezetű és olcsó, ugyanakkor zajos és magas üzemi rezonanciával bír. A rotorvezérlésnél a stabilizálásban segít a lapátokra merőlegesen elhelyezett rudak végén lévő súlyok giroszkópikus hatása.

A kétágú főrotor magas vibrációs szintje a sárkányszerkezetet - a többrotoros helikoptertípusokkal összevetve fokozottabban terheli. Két független, 70 bar nyomáson üzemelő hidraulikarendszer szolgálja ki a rotorok állásszög-szabályozásán alapuló kormányrendszert. A szivatytyúk a főreduktorról kapják a meghajtást. Az elektromos energia ellátást és a hajtóművek indítását két egyenáramú indítómotor-generátor biztosítja.

Az évek során a fedélzeti elektronikát is korszerűsítették, ennek eredményeképpen a helikopter megkapta az amerikai Szövetségi Légügyi Hatóság (FAA) engedélyét az egyetlen pilótával végzett IFR (műszeres) repülésre.

A fegyverzet - a légiművelet követelményei szerint - különböző modulokból állítható össze. (2. táblázat.) Függeszthető - többek között - 2-2 db 7 vagy 19 csöves 70 mm-es rakétablokk, illetve 12,7 mm-es géppuskakonténer, felszerelhető két ajtógéppuska és egy GAU-17 típusú $7,62 \mathrm{~mm}$-es automata géppuska, amely a pilóta által is vezérelhető.

A helikopter törzsét úgy alakították ki, hogy abban akár keresztben is elférjenek a hordágyak, amelyek behelyezését a nagy méretű, hátra csúsztatható oldalajtók könnyítik meg mindkét oldalon. A helikopter törzsében puhafalú tüzelőanyag-tartályokat helyeztek el.

\section{Az UH-1-ES MŰ́SZAKI TULAJDONSÁGAI, KÉPESSÉGEI}

A helikopter személyzete 3-4 fő: 1-2 pilóta és további 2 fegyverkezelő. Összesen 13 katona, 10 ejtőernyős vagy 6 hordágy szállítására alkalmas.

Az UH-1-es helikopter egyik hátránya a viszonylag alacsony maximális sebessége. A korai változatoknál ez egy 820-1050 kW-os hajtóművel $220 \mathrm{~km} / \mathrm{h}$, míg a későbbi, erősebb hajtóművel szerelt változatoknál $260 \mathrm{~km} / \mathrm{h}$ érték. (A legutolsó, Y változat $366 \mathrm{~km} / \mathrm{h}$-ás sebességéhez két hajtómü, mintegy 3000 LE teljesítményére volt szükség.)

Hatótávolságuk változattól függően 420-650km. (Utóbbi érték azonban teljes terhelésnél 200 km-re csökkent.) A típus legnagyobb repülési magassága 5900 méter. Hasznos terhelése $2300 \mathrm{~kg}$ külső horgon, illetve 250 kg csörlőn.

A tehertér ürtartalma mintegy $7 \mathrm{~m}^{3}$. A nagy méretű oldalajtó biztosítja a deszant számára a gyors gépelhagyást. A helikoptert kétoldalt az ajtóknál elhelyezkedő kiforduló horoggal is ellátták, ami lehetővé teszi a deszant lecsúszóköteles (Fast Rope) ereszkedését. SPIES Rope (Special Patrol Insertion/Extraction System - különleges raj berakó/kiemelő kötél) kiemelő kötéllel 6 fő mozgatható.

Csúszótalpas futóműve egyszerű, könnyű és megbízható, ám növeli a helikopter légellenállását. Hátránya még ennek a megoldásnak, hogy az állóhelyeket a gép csak a levegőben hagyhatja el, illetve az is, hogy a leszállást követően bonyolítja a földi mozgatást. A helikopter földi mozgatásához ugyanis kiegészítő felszerelés szükséges: a csúszótalp hátsó harmadában - a gép súlypontjánál - rögzíthető a kerekes vendégfutó. Ezt követően néhány fő, a faroktartónál kézi erővel megemelve, könnyedén a kívánt helyre tolhatja a gépet.

Az infravörös, önirányítású hordozható légvédelmi rakéták elleni védelem eszközei a hajtóművek fölé felszerelt ALQ-144-es infrasugárzást kibocsátó lámpa, hagyományos infracsapda szóró kazetták, illetve a későbbi változatoknál az AN/AAR-47-es automatizált önvédelmi rendszer (a helikopter orrán és farokrészén elhelyezett négy optikai érzékelő, a lézeres besugárzásjelző detektorai, az integrált fedélzeti zavaró rendszer és a szabályozott üzemü infracsapda szórók összessége). Mindezt az AN/APR-39es radarbesugárzás-jelző rendszer egészíti ki. A tengerészgyalogság UH-1N gépeit ellátták még FLIR berendezéssel is. Ez az orr alatti forgatható kupolában helyezkedik el, és lehetővé teszi az éjszakai bevethetőséget.

A két hajtóműves $N$ variánsnál - a kezdetekhez képest - hozzávetőleg megnégyszerezték a hajtómű teljesítményt. Ez jelentősen javította a teheremelő képességet és a fegyverzeti terhelést, de egy harceszköznél a hajtómú duplikációnak nagy a jelentősége a túlélőképesség-növelés szempontjából is.

\section{TÍPUSVÁLTOZATOK}

Az első változatokból még csak pár száz készült, azonban már sorozatgyártású katonai típus volt $\mathrm{HU}-1 \mathrm{~A}$ jelzéssel. 1962-től a típusjelzés UH-1A lett.

1962-ben jelent meg a több rotor- és hajtómű-módosításon átesett B „Gunship” változat, akkortól tekinthetjük a Huey-t kiforrott, nagy sorozatban gyártott helikopternek.

Néhány évvel később kidolgozták a $C$ jelű, támogató helikopter szerepre szánt változatot is. 1972-ben már egy $43 \mathrm{db}$ UH-1-es helikoptert alkalmazó légi tüzérosztályt rendszeresítettek a helikopteres légimozgékony hadosztály szervezetében, amelynek helikoptereit levegő-föld rakétakonténerrel szerelték fel. Az oldaltartókra GAU 16 típusú 


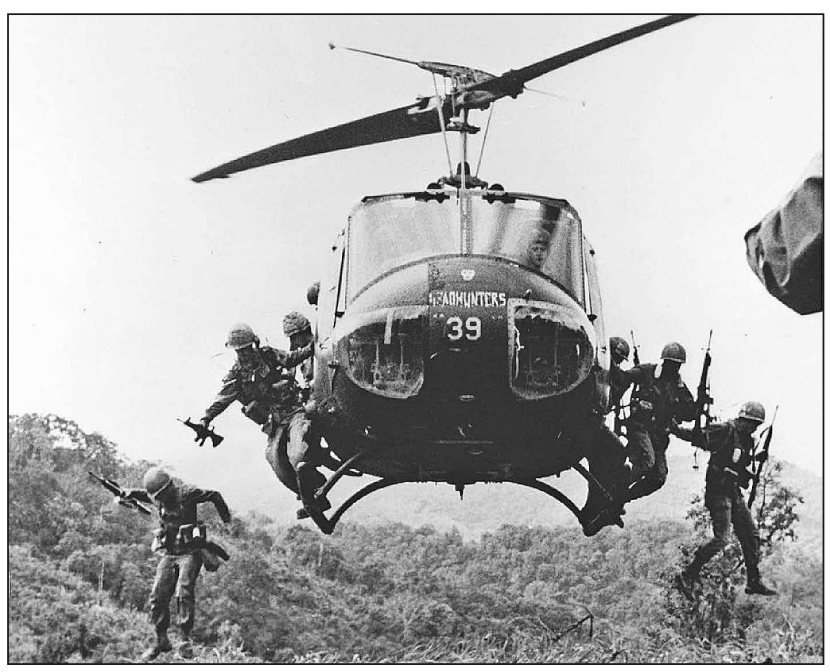

4. ábra. Lövészdeszant kirakása lebegésből Vietnamban

12.7 mm-es géppuskát, vagy mozgatható hatcsövű géppuskákat szereltek, ezeket a pilóták müködtethették távvezérléssel.

A korai Huey helikopterek fedélzetén 10 fő volt a szállítható felfegyverzett deszantként, illetve $1400-1800$ kg hasz- nos terhet szálíthattak. E paraméterek alapján a helikopter akkor a könnyű szállító kategória felső határán helyezkedett el.

Vietnamban azonban már a meghosszabbított törzsű $D$ változatot is szolgálatba állították. Az UH-1D (Bell 205-ös modell) 1963-ban jelent meg. 1050 mm-rel meghosszabbított törzzsel és nagyobb forgószárny-átmérővel készült, mint a megelőző változatok, növekedett a hatótávolsága is, erősebb hajtóművekkel is ellátták, így az eredeti Lycoming T53-L-11-es, (1100 LE) hajtómű helyére a Lycoming T53L-13-as (1400 LE) hajtómü került. A legfeltűnőbb különbség a nagy méretű tehertérajtó, amelyeket a gép mindkét oldalára elhelyeztek. Az UH-1D-t, 12 fő katona szállítására tervezték. Személyzete 2 fő, hatótávolsága 467 km, sebessége $210 \mathrm{~km} / \mathrm{h}$. A Huey fegyverzete: az ajtókban elhelyezett $2 \mathrm{db}$ M60D géppuska, a $20 \mathrm{~mm}$-es gépágyú, 40 mm-es gránátvető, $70 \mathrm{~mm}$-es nem irányított rakéta és legfeljebb hat db NATO szabványos AGM-22B (korábban SS-11B) páncéltörő rakéta. Felszerelhető még az M60D 7,62 mm-es, vagy az M213.50 cal. géppuska a gép orrrészébe.

Az UH-1H, további fejlesztések eredményeként, már 13 főt szállíthat. Ez a változat érte meg a legnagyobb sorozatszámot. Az UH-1D-t Németország, az UH-1H-t pedig Törökország és Taiwan is gyártotta licencszerződés alapján. Az UH-1D változatból 2000, a korábbinál kétszer nagyobb

1. táblázat. Az UH-1-es helikopter föbb típusváltozatai ${ }^{3}$

\begin{tabular}{|c|c|c|c|c|c|c|c|}
\hline & UH-1A & UH-1B & $\mathrm{UH}-1 \mathrm{C}$ & UH-1D & UH-1H & UH-1N & UH-1Y \\
\hline Megjelenés éve & 1960 & 1961 & 1966 & 1961 & 1966 & 1969 & 2001 \\
\hline Módosítás & - & $\begin{array}{l}\text { hosszabb } \\
\text { törzs, } \\
\text { fegyverzet, } \\
\text { erősebb } \\
\text { hajtómű }\end{array}$ & $\begin{array}{c}\text { növelt } \\
\text { fegyver- } \\
\text { tömeg, } \\
\text { hosszabb } \\
\text { rotor-lapát, } \\
\text { erősebb } \\
\text { hajtómű } \\
\end{array}$ & $\begin{array}{l}\text { hosszabb } \\
\text { törzs, } \\
\text { nagyobb } \\
\text { tehertér- } \\
\text { ajtó, } \\
\text { erősebb } \\
\text { hajtómű }\end{array}$ & $\begin{array}{l}\text { erősebb } \\
\text { hajtómű }\end{array}$ & $\begin{array}{c}\text { két erősebb } \\
\text { hajtómű, } \\
\text { hosszabb } \\
\text { rotorlapát }\end{array}$ & $\begin{array}{c}\text { négy } \\
\text { lapátos kompozit } \\
\text { rotor, infrav. } \\
\text { kamera, } \\
\text { üzemanyag } \\
\text { semlegesgáz- } \\
\text { rendszer }\end{array}$ \\
\hline $\begin{array}{l}\text { Hosszúsága } \\
\text { rotorral }\end{array}$ & $17,4 \mathrm{~m}$ & $17,4 \mathrm{~m}$ & $17,4 \mathrm{~m}$ & $17,4 \mathrm{~m}$ & $17,4 \mathrm{~m}$ & $17,46 \mathrm{~m}$ & $17,78 \mathrm{~m}$ \\
\hline Magassága & $4,4 \mathrm{~m}$ & $4,4 \mathrm{~m}$ & $4,4 \mathrm{~m}$ & $4,4 \mathrm{~m}$ & $4,4 \mathrm{~m}$ & $4,54 \mathrm{~m}$ & $4,44 \mathrm{~m}$ \\
\hline Szerkezeti tömege & $2365 \mathrm{~kg}$ & $2300 \mathrm{~kg}$ & $2350 \mathrm{~kg}$ & $2350 \mathrm{~kg}$ & $2398 \mathrm{~kg}$ & $2786 \mathrm{~kg}$ & $5370 \mathrm{~kg}$ \\
\hline $\begin{array}{l}\text { Tömege tüzelö- } \\
\text { anyaggal feltöltve }\end{array}$ & $4100 \mathrm{~kg}$ & $4309 \mathrm{~kg}$ & $4309 \mathrm{~kg}$ & $4309 \mathrm{~kg}$ & $4308 \mathrm{~kg}$ & $4767 \mathrm{~kg}$ & $6540 \mathrm{~kg}$ \\
\hline Hasznos teher & $1300 \mathrm{~kg}$ & $1361 \mathrm{~kg}$ & $2120 \mathrm{~kg}$ & $2000 \mathrm{~kg}$ & $1759 \mathrm{~kg}$ & $2038 \mathrm{~kg}$ & $3020 \mathrm{~kg}$ \\
\hline Utaslétszám & 9 fő & 9 fő & 9 fő & 12 fö & 13 fö & 14 fö & 13 fö \\
\hline Hajtómú szám & $1 \mathrm{db}$ & $1 \mathrm{db}$ & $1 \mathrm{db}$ & $1 \mathrm{db}$ & $1 \mathrm{db}$ & $2 \mathrm{db}$ & $2 \mathrm{db}$ \\
\hline $\begin{array}{l}\text { Hajtómú típus, } \\
\text { teljesítmény }\end{array}$ & $\begin{array}{c}\text { Lycoming } \\
\text { T-53-L-1A } \\
770 \text { LE }\end{array}$ & $\begin{array}{l}\text { Lycoming } \\
\text { T-53-L-5 } \\
716 \text { kW } \\
\text { (974 LE) }\end{array}$ & $\begin{array}{l}\text { Lycoming } \\
\text { T-53-L-11 } \\
1100 \text { LE }\end{array}$ & $\begin{array}{c}\text { Lycoming } \\
\text { T-53-L-11 } \\
1100 \text { LE }\end{array}$ & $\begin{array}{c}\text { Lycoming } \\
\text { T-53-L-13 } \\
1050 \mathrm{~kW} \\
(1430 \mathrm{LE})\end{array}$ & $\begin{array}{c}\text { Pratt\& } \\
\text { Whitney } \\
\text { T400CP400 } \\
2 \times 962 \mathrm{~kW} \\
(2 \times 1307 \text { LE })\end{array}$ & $\begin{array}{c}\text { General Electric } \\
\text { T700GE401C } \\
(2 \times 1546 \text { LE) }\end{array}$ \\
\hline $\begin{array}{l}\text { Maximális } \\
\text { sebesség }\end{array}$ & 220 km/h & 238 km/h & 240 km/h & $240 \mathrm{~km} / \mathrm{h}$ & $240 \mathrm{~km} / \mathrm{h}$ & $260 \mathrm{~km} / \mathrm{h}$ & $366 \mathrm{~km} / \mathrm{h}$ \\
\hline Hatótávolság & $420 \mathrm{~km}$ & $615 \mathrm{~km}$ & $510 \mathrm{~km}$ & $510 \mathrm{~km}$ & $510 \mathrm{~km}$ & 320 km & 648 km \\
\hline $\begin{array}{l}\text { Maximális repülési } \\
\text { magasság }\end{array}$ & $5900 \mathrm{~m}$ & $5790 \mathrm{~m}$ & $4000 \mathrm{~m}$ & $4000 \mathrm{~m}$ & $3810 \mathrm{~m}$ & $4331 \mathrm{~m}$ & $6100 \mathrm{~m}$ \\
\hline $\begin{array}{l}\text { Legyártott } \\
\text { mennyiség }\end{array}$ & $500 \mathrm{db}$ & $766 \mathrm{db}$ & $1500 \mathrm{db}$ & $2200 \mathrm{db}$ & $5435 \mathrm{db}$ & $1000 \mathrm{db}$ & n.a. \\
\hline
\end{tabular}


teljesítményű T53-L-13B hajtóművel szerelt H-ból pedig $5435 \mathrm{db}$ készült.

$\mathrm{Az} U \mathrm{UH}-1 \mathrm{~N}$ két gázturbinás hajtóművel felszerelt, növelt teljesítményű, magasabb üzembiztonságú és harci túlélő képességű változat, főleg a tengerészgyalogság alkalmazza. Hajtóműve 2 db Lycoming T53-L-13B gázturbina, vagy $2 \mathrm{db}$ Pratt and Whitney T400-CP-400-as gázturbina 1290 LE teljesítménnyel. $\mathrm{Az} U \mathrm{UH}-1 \mathrm{~N}$ változat szerkezeti tömege már 2786 kg, maximális felszáló tömege 5080 kg. Hossza 17,46 m; magassága 4,54 m. A forgószárny átmérője 14,62 m. Repülési magassága 4331 m, felszálló tömege 4767 kg. Hatótávolsága $320 \mathrm{~km}$. Személyzete: 2 fő tiszt; 2 fő tiszthelyettes.

$\mathrm{Az}$ UH-1N változatnál hazánkkal kapcsolatban érdemes külön kitérőt tenni. 2010 közepén az USA az ún. EDA (Excess Defense Articles) program keretében a Honvédelmi Minisztériumon keresztül felajánlotta hazánknak is megvásárlásra a haderejéből kivonásra tervezett ${ }^{1} \mathrm{UH}-1 \mathrm{~N}$ típusú helikoptereket, darabonkénti kb. 5 millió USD-s áron. Ugyanezen év végén az ajánlatot tovább pontosította az amerikai fél, azzal a jelentős változással, hogy a használt helikopterek átadásra kerülhetnek Magyarország részére térítésmentesen, mivel hazánk a „Grant Eligible2" besorolású országok közé tartozott. Fontos hangsúlyozni, hogy a térítésmentes átvétel lehetősége alatt az USA az ún. „as is where is" állapotot értette, azaz csak a helikopterekre vonatkozott az akkori állapotukban. A hajózó és repülő-müszaki állomány kiképzése, a helikopterek esetleges javítása, átalakítása, modernizációja, hazaszállítása, az alkatrészbázis kialakítása az átvevő felet terhelte volna.

A HM tárca 2010 végén, a térítésmentes átvétel lehetőségének fényében elkezdte vizsgálni a felajánlást, és összeállított egy képességcsomag igényt, amely $30 \mathrm{db}$ UH-1N helikopter átvételét, javítását, kismértékű modernizációját, a személyi állomány képzését, nagy mennyiségü kiegészítő felszerelést, és több éves logisztikai támogatási csomagot takart. A programot 2013 elején végül is elvetette a $\mathrm{HM}$.

A HH-1N változat a kutató-mentő feladatokra kialakított változat. Az UH-1V MEDEVAC változat hat fekvő sérült szállítására alkalmas.

\section{2. táblázat. Az UH-1-es helikopter fegyverzeti rendszerei}

\begin{tabular}{|c|c|}
\hline ХМ3, ХМЗЕ1/M3 & ARA $^{4}$ rakétablokk $2 \times 70 \mathrm{~mm}\left(2.75{ }^{\prime \prime}\right) 24$ csöves, Mk8 irányzék. ${ }^{5}$ \\
\hline TLSS $^{6}(1964)$ & Gránátvető - M8-as füstgránátok, M6-os és M7-es könnygázgránát. \\
\hline XM5/M5 & Orrban 1×40mm M75-ös gránátvető, pilóta vezérelte. ${ }^{7}$ \\
\hline XM156/M156 & M6-os sorozat. 4×M60C $7.62 \times 51 \mathrm{~mm}$. (UH-1B/C) géppuskák univerzális tartón. \\
\hline XM9 & XM6/M6-os modul + 2×M75-ös gránátvető. \\
\hline XM11 & XM70-es irányzékkal 6×AGM-22A (SS.11) rakéta. \\
\hline XM22 & XM58 irányzék, XM156 univerzális tartón 6xAGM-22B rakéta. \\
\hline Maxwell-rendszer & $\begin{array}{l}\text { M3-as és XM11-es modulok hibridje, } 24 \text { helyett csak } 12 \text { vagy } 18 \mathrm{db} 70 \mathrm{~mm} \text { rakéta + 2×AGM- } \\
\text { 22A rakéta. }{ }^{8}\end{array}$ \\
\hline XM16/M16 & $\begin{array}{l}\text { M6-os + 2×M157-es vagy M158-as } 70 \text { mm-es } 7 \text { csöves rakétaindító M156-os tartón, M60 } \\
\text { reflex irányzékkal. }\end{array}$ \\
\hline XM17 & „Kellet tartó” 2×XM159-es 70 mm-es rakétaindító. \\
\hline XM21/M21 & Alaprendszerré vált: XM16/M16-os 4×M60C helyett 2×M134-es, 7.62×51 mm-es Minigun. \\
\hline M23 (XM23/M23) & Kabinajtóknál 1-1 db M60D 7.62×51 mm-es géppuska. ${ }^{9}$ \\
\hline XM26 (1968) & 6×BGM-71 TOW rakéta „teszt” jelleggel. \\
\hline XM29 & Sagami tartóval. ${ }^{10}$ Rövid törzsűek (UH-1B/C) kabin ajtóinál M60D 7.62×51 mm-es géppuska. ${ }^{11}$ \\
\hline XM30 & XM156/M156-os tartón minden irányban mozgatható 2×XM140-es, 30 mm-es gépágyú. ${ }^{12}$ \\
\hline XM31 & 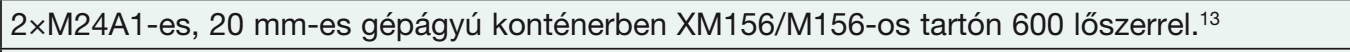 \\
\hline XM50 & XM5/M5-ös + XM21/M21-es. \\
\hline M56 & 2×SUU-13D/A kazettás aknakonténer megerősített M156-os tartóval. (UH-1H). \\
\hline XM59/M59 & XM213/M213-as .50 cal. géppuska vagy XM175-ös, 40 mm-es gránátvető beépítése. ${ }^{14}$ \\
\hline XM93/XM93E1 & 2×M134-es, $7.62 \times 51$ mm-es Minigun az ajtókban. ${ }^{15}$ \\
\hline XM93E1 & Pilóta által vezérelt előre néző fegyverek, M60-as reflex irányzékkal. \\
\hline XM94 & $\begin{array}{l}\text { XM93-as moddolása, M129-es, } 40 \text { mm-es gránátvető a M134-es, 7.62×51 mm-es Minigun } \\
\text { mellett }\end{array}$ \\
\hline A/A49E-3 & 2×M134-es, 7.62×51 mm-es Minigun hosszú törzsűeknél a kabinajtóknál (UH-1N). ${ }^{16}$ \\
\hline A/A49E-11 & $\begin{array}{l}\text { DAS }^{17}, 2 \times \text { GAU-15/A és GAU-16/A .50 cal. géppuska vagy GAU-17/A 7.62×51 mm-es Minigun, } \\
\text { vagy } 2 \times B R U-20 / A \text { vagy BRU-21/A } 70 \text { mm-es rakétaindítók hosszú törzsűeknek. (UH-1N). }\end{array}$ \\
\hline TK-2 & $\begin{array}{l}4 \times M 60 \mathrm{C} 7.62 \times 51 \mathrm{~mm} \text {-es géppuska + } 2 \text { tartó további fegyverzetnek. } 7 \text { csöves } 70 \mathrm{~mm} \text { rakéta } \\
\text { indító. }^{18}\end{array}$ \\
\hline Emerson TAT-101 & $\begin{array}{l}\text { Emerson Electric TAT-101'19 az orrban került kialakításra. } 2 \times \text { M60-as géppuska } 1000 \\
\text { lőszerrel. }{ }^{20}\end{array}$ \\
\hline Emerson Mini-TAT & Kanadai UH-1N részére, M60-as helyett Minigun. \\
\hline
\end{tabular}




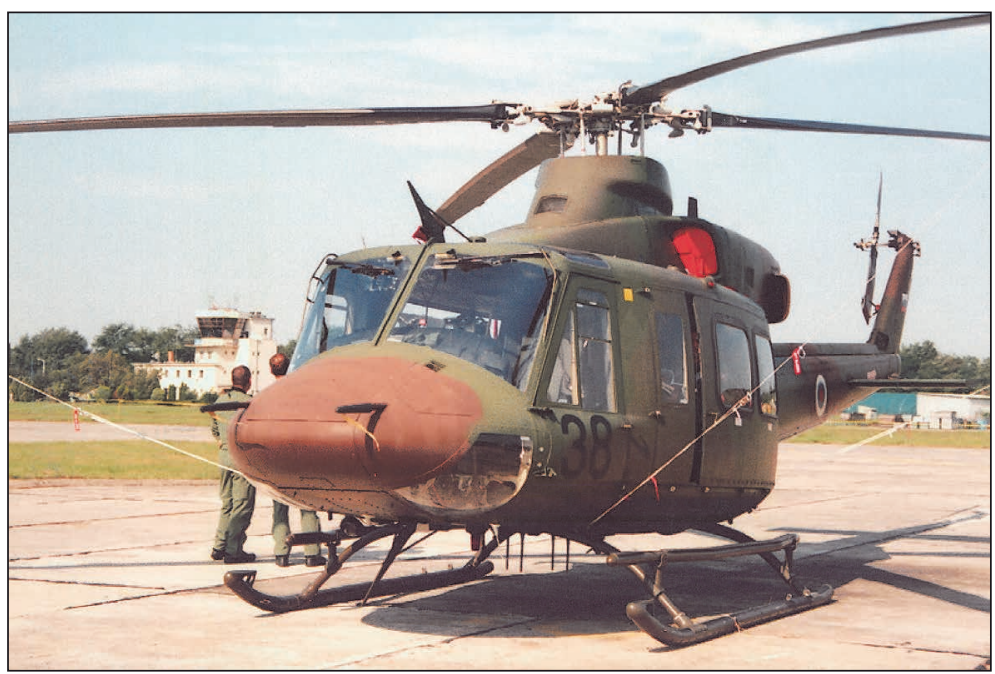

5. ábra. Szlovén Agusta-Bell AB-412-es (Fotó: Baranyai László)

Az UH-1Y az UH-1N leváltására készített korszerűsített változat. Jelenleg a továbbfejlesztett Huey II az aktuális sorozatgyártású UH-1. Minden gép fülkéje NVGkompatibilis, emellett ellátták taktikai navigációs rendszerrel (TACAN) is.

Vietnamban a Huey-kat több feladatkörben is alkalmazták. Földi célok támadására vagy páncélozott kísérőként történő alkalmazás esetén gránátvetőkkel, rakétaindító blokkokkal, géppuskákkal szerelték fel. 1962-től már helyben készültek a különböző fegyverzet-kombinációk tartói, a „Gunship” elnevezést leváltották a felszereltségre utaló elnevezések:

- rakéták felépítése esetén „Frog” vagy „Hog”;

- csak gépfegyver esetén "Cobra” vagy „Gun” (innen fejlesztették ki az AH-1 Cobrát);

- csapatszállító fegyverkonténer nélkül: „Slick”.

A két hajtóműves Bell 212 Kanadában is készült, a Bell ottani leányvállalata e változatból 1000 db-nál többet állított elő. Az utóbbi évtized terméke az erősebb hajtóművel szerelt 214 Huey Plus, illetve a Bell 412-es is. A Bell 1979re dolgozta ki ezt a négyágú fő rotorral szerelt változatot.

A Bell Helicopter Company eladta az UH-1-es gyártási licencét az olasz Agusta S.p.A.-nak. Az AB-204B helikopter az UH-1B alaptípus olasz gyártású változata. 1980-ban a típus erősebb és megnövelt méretü változata, az $A B-212-e s(\mathrm{UH}-1 \mathrm{~N})$ is megjelent. A helikoptert AB-412-es típusjelzéssel gyártották. Ebből vásárolt a szomszédos Ausztria és Spanyolország is. $\mathrm{Az} U \mathrm{UH}-1 \mathrm{~J}$ változatot licenc alapján Japánban gyártották.

Vietnamban az UH-1 Iroquis helikopterek oldalajtóihoz, majd oldalára és csúszótalpaira szereltek különböző géppuskákat, később pedig nem irányított rakétákkal is felfegyverezték azokat. Probléma volt azonban a Huey-k elégtelen védettségével. A helikopterek akár gépkarabéllyal is leküzdhetőek voltak. A célzás pontossága, és a hordozható fegyverek, lőszerek mennyisége sem volt megfelelő. A vietnami háború végére a végleges helikopter-veszteség 1900 db esetében harctevékenység, további 2300 db-nál pedig műszaki hiba, baleset miatt következett be.

A vietnami háborús csúcshoz képest napjainkra az amerikai szárazföldi haderőnemnél csak csekély számú UH-1-es teljesít szolgála- tot, mert az UH-60 Black Hawk leváltotta a típust.

A tengerészgyalogság viszont ma is nagy számban tartja rendszerben az N és az új Y típusváltozatokat. Itt meg kell említeni, hogy az UH-1N és $Y$ típust párhuzamosan üzemeltetik az $\mathrm{AH}-1 \mathrm{~W}$ és $\mathrm{Z}$ harci helikopter típussal. $\mathrm{A}$ két típus alkatrészei, javítási, karbantartási technológiája közel 80\%-ban megegyezik, így a párhuzamos üzemeltetés olcsóbb, könnyebb, ami egy hajó fedélzetén, erősen korlátozott lehetőségek között jelentős előny, és ez nagyon fontos szempont a tengerészgyalogságnál.

A korábban említett magyar program egyik eleme volt egy helyszíni szemle is a Naval Air Station Patuxent River bázison, amely az amerikai haditengerészet és tengerészgyalogság repülőinek kísérleti bázisa is. Az ott bemutatott UH-1N nem a legmodernebb típus, de a tengerészgyalogság a folyamatosan változó alkalmazási igényeknek megfelelően modernizálta az N változatot, így az a 2010-es évek elején is megállta a helyét a világ bármely pontján, bármilyen konfliktusban, ahol az US Marine Corps részt vett.

Bár a helikopter műszerezettsége alapvetően analóg műszerekre épült, de a helikopterek fülkevilágítása NVG kompatibilis rendelkeztek taktikai navigációs rendszerrel (TACAN), nappal és éjjel, egyszerü és bonyolult időjárásban is alkalmazhatók. Minden helikoptert felszereltek hőkamerával, UHF/NHF/HF/SATCOM rádió-berendezéssel, fedélzeti hangrögzítő berendezéssel, feladattervező rendszer beviteli egységével, önvédelmi berendezéssel (rakéta-közeledésjelző, radar-besugárzásjelző, zavarótöltet szóró berendezés), 5000 pound (kb. 2300 kg) kapacitású külsőfüggesztő horoggal, 600 pound (kb. 250 kg) kapacitású fedélzeti csörlővel, vezetékvágó berendezéssel. Továbbá az éjjellátó szemüveghez rendszeresítettek egy a szemüvegre illeszthető ún. Head Up Display-t, amely lehetővé tette a személyzet számára, hogy a helikopter rendszereinek müszaki paramétereit, a repülési paramétereket a személyzet szeme elé vetítse, így annak nem kellett folyamatosan a szemüveg alatt betekintenie a müszerfalra, ezzel jelentősen csökkentették az NVG-s repülések személyzetre rótt terhelését.

\section{6. ábra. Az Egyesült Államok tengerészgyalogságának (US Marine Corps)} UH-1N fülkéje (Fotó: Baranyai László)

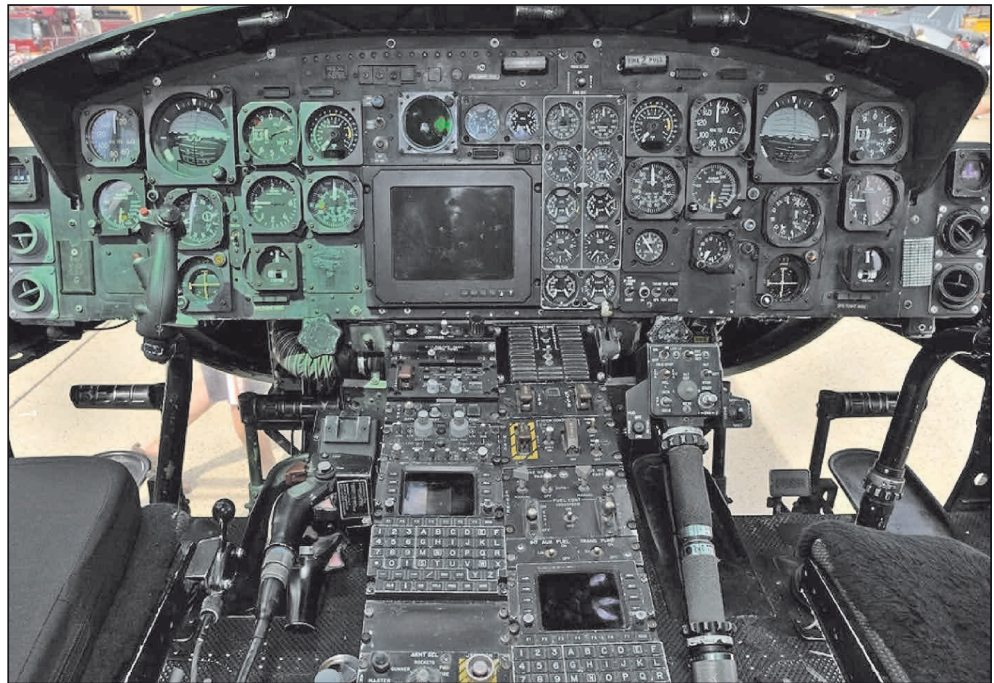




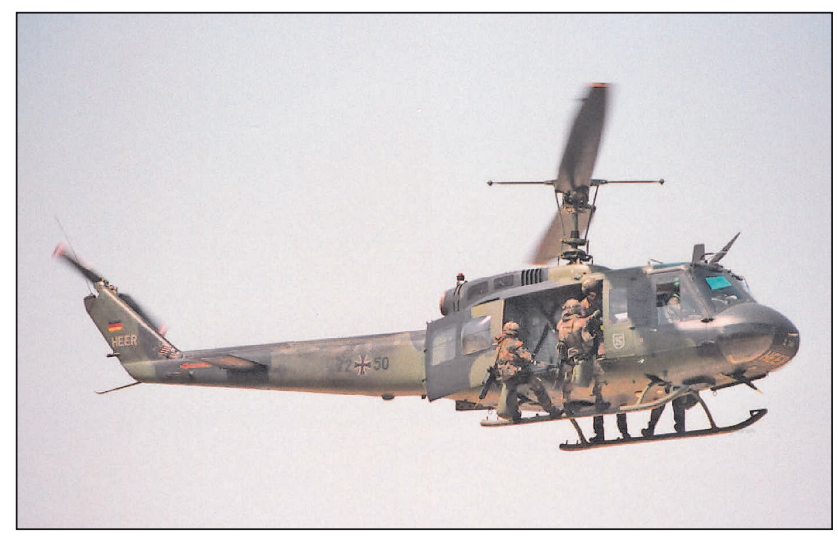

7. ábra. Német UH-1D (Fotó: Baranyai László)

A magyarok számára felajánlott program használt UH-1N keretében felmerült, hogy az átvétel során a gyártó Bell Helicopters, az általa kidolgozott, ún. „mid-life update” programmal modernizálja a helikoptereket. Ezzel a modernizációval lecserélték volna a hajtóműveket a Pratt and Whitney Canada (PWC) PT6 ${ }^{21}$-os gázturbinás erőforrás újabb változatára, ezzel együtt a főreduktort, illetve a faroktartót egy ún. „fast fin” faroktartóra, továbbá a teljes műszerezettséget modern "glass cockpit”-ra. Természetesen ez költséges lett volna, viszont további 25 évig szolgál-

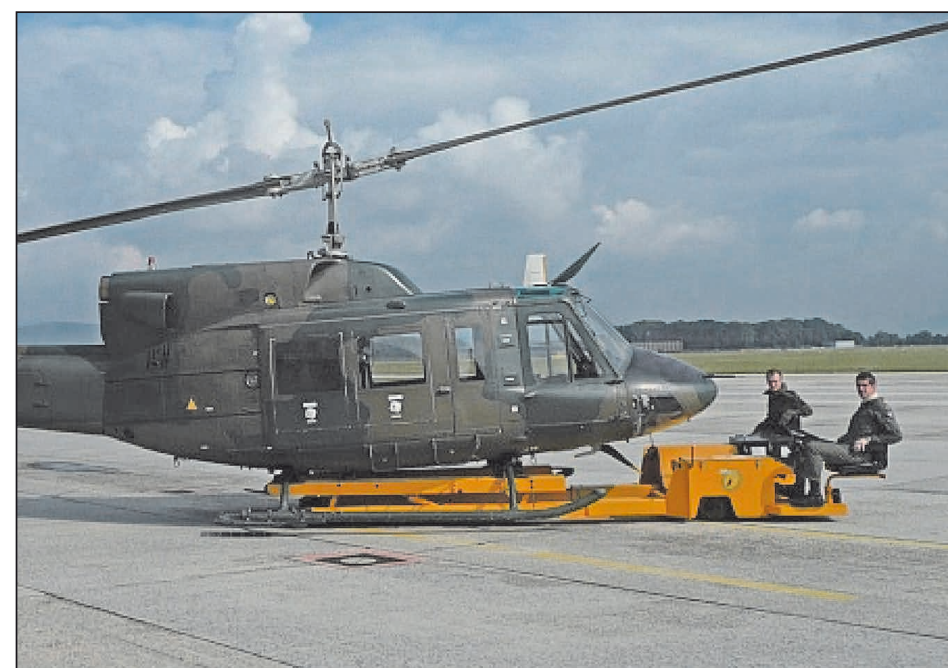

9. ábra. Az UH-1N olasz változata, az AB-212-es. A merevfutós helikopter földi mozgatása speciális eszközt (pl. elektromos szállítókocsit, vagy kerekes vendégfutót) igényel

hatta volna a modern UH-1N a hazai haderőt. Németország az 1990-es évekig alkalmazta széleskörüen, napjainkban azonban már csak másodlagos katonai, illetve rendvédelmi feladatokra alkalmazzák.

8. ábra. Két hajtóműves UH-1N a tenger felett. A két hajtómű nyújtotta többletrepülési biztonság tenger és település feletti repülésnél különösen fontos

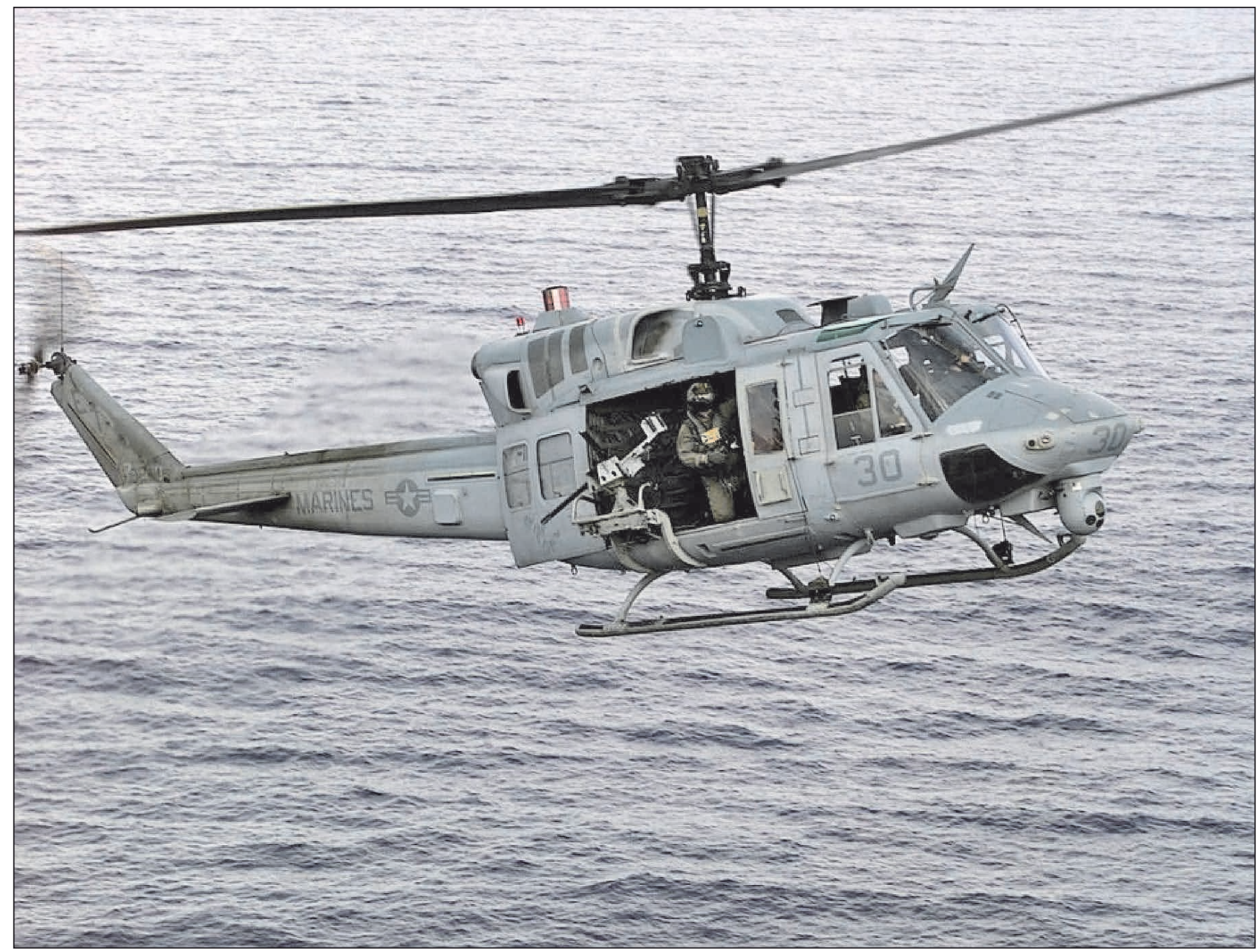




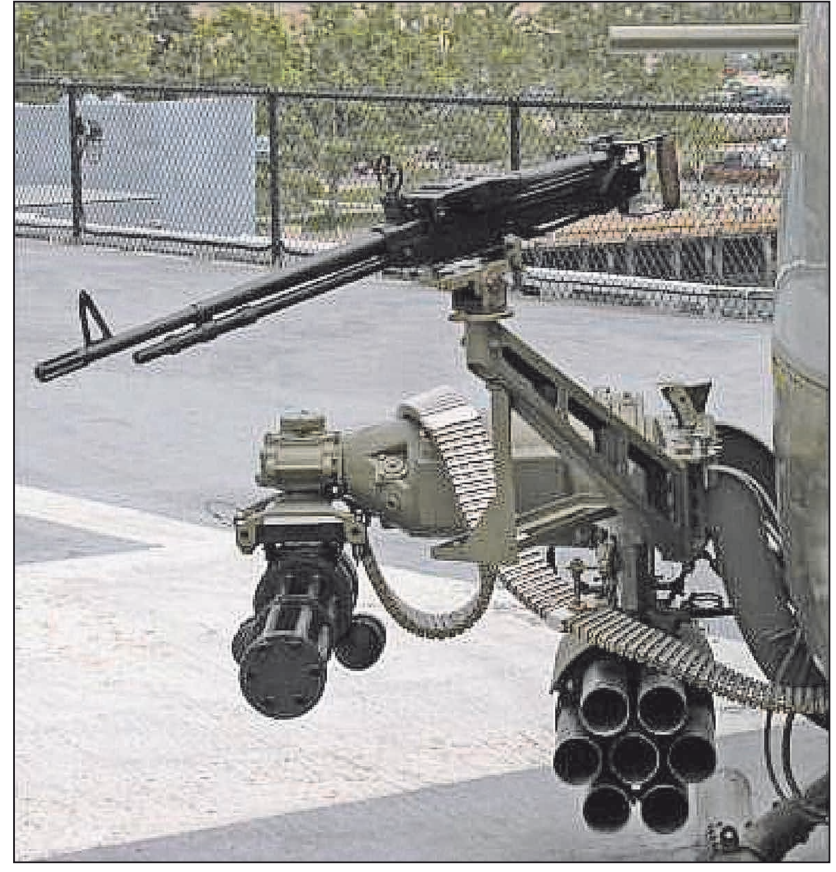

10. ábra. Az UH-1 Gunship (felfegyverzett támogató helikopter) fegyverzete

Az UH-1Y típusváltozatnál már a fegyverzet közel azonos az $\mathrm{AH}-1 \mathrm{Z}$ harci helikopter fegyverzetével. A legmodernebb Huey képes mindazon fegyverzet szállítására és célba juttatására, mint egy modern harci helikopter, de továbbra sem lesz harci helikopter. Az irányított páncéltörő rakéták alkalmazása továbbra is a harci helikopterekre jellemzőek, de a könnyü, a 70 mm-es nem irányított Hydra rakéták modernizált, lézervezérlésű, irányított változatait előszeretettel alkalmazzák, csakúgy, mint a többfajta géppuskát, minigun-t, amellyel a harcoló szárazföldi csapatoknak tüztámogatást nyújthat a Huey a CCA (close combat attack) során.

Ha az UH-1N vagy inkább az Y változatot képességét és használhatóságát kellene elemezni, akkor a helikopter kis létszámú egységek gyors szállítására és számukra tűztámogatás biztosítására szolgál, azaz a különleges műveleti feladatokra nagyon kiváló.

\section{ForRÁSOK}

[1] Bali Tamás: A helikopterek NATO elvek szerinti alkalmazásának doktrinális kérdései. Repüléstudományi közlemények, 2011. XXIII. évf. 1. szám;

[2] Batchelor, John; Love, Malcolm: A repülés enciklopédiája 1945-2005. Bp.: Gabo kiadó, 2006. ISBN 9789639635821:

[3] Gunston, Bill: Modern helikopterek. Debrecen: Phoenix Könyvkiadó, 1993. ISBN 9637457615;

[4] High-tech armor for helicopters. Tejin Twaron BV, Arnhem, www.twaron.com (2004.09.);

[5] Jackson, Paul (szerk.): Jane's All the World's Aircraft 2009-2010. Couldson, UK, 2009. ISBN 9780710628800, 268-269. p.;

[6] Ryan, M.; Mann, C.; Stilwell, A.: A világ különleges katonai alakulatai. Bp.: Ventus Libro Kiadó, 2003. ISBN 0579000408340, 23. p.;

[7] Szentesi György: Katonai helikopterek. Bp.: Zrínyi Katonai Kiadó, 1986.;
[8] Vass Balázs: Repülőgépek, helikopterek, rakéták. Bp.: Műszaki könyvkiadó, 1982.;

[9] Bishop, Chris: Bell UH-1 Huey 1962-75. Oxford, Osprey Publishing, 2003.;

[10] Dr. Hegedűs Ernő: Az UH-1 helikopter fejlesztésének története és korszerüsítésének lehetőségei. In: Katonai Logisztika 2016. 24. évf. (3.) k. szám, 216-244. p.;

[11] Dr. Csutorás Gábor: Az UH-1N típusú helikopter baleseti tűzoltás-mentésének kérdései. In Repüléstudományi Közlemények 2012. 24. évf. 2. sz., p. 460-470. http://www.repulestudomany.hu/ kulonszamok/2012_cikkek/35_Csutoras_Gabor.pdf [2018.04.17];

[12] Horváth Zoltán: A Walkürök lovaglása - ötvenéves a Bell UH-1-es Iroquois AranySas, 2006. 6. évf., 10. szám, p. 50-55.

\section{JegYzeteK}

1 Az Amerikai Egyesült Államok hadereje a helikopter modernizációs program keretében 2010-től 5 éven át $84 \mathrm{db} U \mathrm{UH}-1 \mathrm{~N}$ és $5 \mathrm{db}$ $\mathrm{HH}-1 \mathrm{~N}$ közepes, többcélú helikopterét tervezte kivonni szolgálatból.

2 Grant Eligible - Azon szövetséges országok csoportja, akik jogosultak az USA haditechnikai eszközeinek térítésmentes átvételére. Az országok ellenőrzése és besorolása évenként történik.

3 A változatok szélesebb körének felsorolása: HU-1A, 1962-től UH-1A, UH-1B, UH-1C, UH-1D, UH-1E - Az UH-1B/C típus tengerészgyalogság számára módosított változata, $U H-1 F-A z$ $\mathrm{UH}-1 \mathrm{~B} / \mathrm{C}$ típus légierő számára módosított változata, $\mathrm{UH}-1 \mathrm{H}$, $\mathrm{HH}-1 \mathrm{~K}-\mathrm{A}$ haditengerészet számára készített tengeri kutató-mentő változat, $\mathrm{UH}-1 \mathrm{~L}-\mathrm{A} \mathrm{HH}-1 \mathrm{~K}$ teherszállító változata, $\mathrm{UH}-1 \mathrm{M}-\mathrm{Az}$ UH-1C támadóhelikopter változata, továbbfejlesztett hajtóművel, UH-1N, UH-1P - Az UH-1F változata a légierő számára, UH-1V katonai mentőhelikopter változat, UH-1Y, Huey II - módosított, továbbfejlesztett, korszerűsített változat, amely az UH-1H-n alapul. 4 Aerial Rocket Artillery.

5 XM3E1 indítócsövei 4"-al hosszabbak. XM3E1 lett M3-ként rendszeresítve.

6 Troop Landing Smoke Screen.

7 Lőszer javadalmazás: 150 vagy 302.

8 Gyakorlati tapasztalatok alapján, a hadműveleti területen lett moddolva.

9 Hosszú törzsű UH-1-esek számára kifejlesztve (UH-1D/H/N).

10 A kabin hátsó részében rögzített pontról kihajtható tartó, főleg UH-1F/P/M típusokhoz. M60D-hez tervezték, 2×M60-as, M2HB géppuskákat vagy M134-es minigunokat is beépítettek a US Navy Seawolves.

11 Külső függesztményekkel nem volt együtt használható.

12 Kísérleti rendszer. Lőszerjavadalmazás: 600 lőszer.

13 Csak függőlegesen állítható.

$14 \mathrm{Az}$ M23-as moddolt változata.

15 Hosszú törzsűeknél (UH-1D/H/N), USAF rövid törzsűeknél (UH-1F/P).

16 USAF által alkalmazva, megfelel az US Army XM93-asnak.

17 Defensive Armament System.

18 Kipróbálták a XM18/M18 Minigun konténert is (USAF SUU-11/A) $\mathrm{CH}-34 / \mathrm{UH}-34-e s e n$ használt TK-1 moddolt változata, USMC fejlesztette ki a TK-2-est (Temporary Kit-2) az UH-1E számára.

19 Tactical Armament Turret-101.

20 Egyedi kialakítású az USMC UH-1E helikopterek számára, 1967 és 1972 között.

$21 \mathrm{Az} U \mathrm{UH}-1 \mathrm{~N}$ típusba eredetileg szerelt T400-as hajtóművet a PWC már nem gyártja, és azt korábban csak az amerikai haderő számára szállította, javítására csak az USA haderje jogosult. A polgári változatokba a PWC PT6T hajtóművet szerelték be, amelyet napjainkban is gyárt a PWC, és a PT6-os hatóműcsalád a világ legmegbízhatóbb turboshaft hajtóműve. 